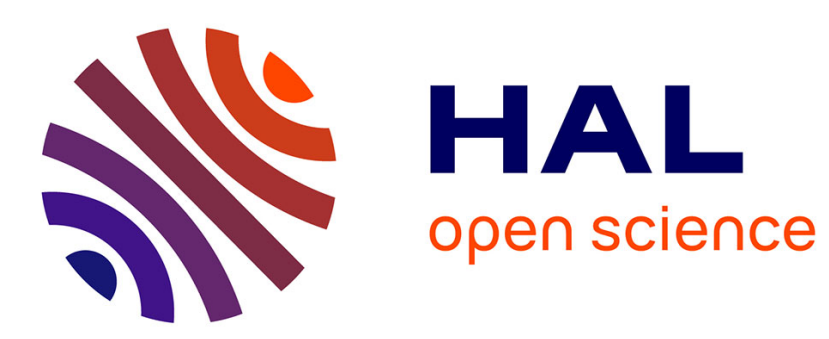

\title{
The behavioral and neoliberal foundations of randomizations
}

\author{
Jean-Michel Servet, Bruno Tinel
}

\section{To cite this version:}

Jean-Michel Servet, Bruno Tinel. The behavioral and neoliberal foundations of randomizations. Strategic Change, 2020, 29 (3), pp.293-299. 10.1002/jsc.2328 . halshs-02562758

\section{HAL Id: halshs-02562758 \\ https://shs.hal.science/halshs-02562758}

Submitted on 4 May 2020

HAL is a multi-disciplinary open access archive for the deposit and dissemination of scientific research documents, whether they are published or not. The documents may come from teaching and research institutions in France or abroad, or from public or private research centers.
L'archive ouverte pluridisciplinaire HAL, est destinée au dépôt et à la diffusion de documents scientifiques de niveau recherche, publiés ou non, émanant des établissements d'enseignement et de recherche français ou étrangers, des laboratoires publics ou privés. 


\title{
The behavioural and neoliberal foundations of randomisations ${ }^{1}$
}

\author{
Jean-Michel Servet
}

honorary professor IHEID, Geneva, jean-michel.servet@graduateinstitute.ch

\section{Bruno Tinel}

associate professor, Sorbonne School of Economics, University of Paris 1 PanthéonSorbonne and CES, btinel@univ-paris1.fr

One-sentence summary :

Randomized controlled trials by behavioural economists pretend to be pragmatic and only interested in what really works to solve practical problems but in reality they have notorious normative and ideological aspects.

Key points:

Behavioural RCTs ignore contexts and composition effects and reflect the biases of those who perform assessments.

Behavioural randomizers presume without demonstrating that market exchanges are the most effective form of regulation for societies in all situations of social life.

The positive or negative incentives ("nudges") offered by behavioural economics aim to normalize the behaviour of consumers, users, employees or small/independent producers. They are part of a set of power devices by which individual behaviours are shaped and forced, without their knowledge, to conform to dominant class interests.

\footnotetext{
${ }^{1}$ JEL codes: A13, B41, C93, G41. EFM Classification codes: 120, 320, 720, 760. Many thanks to Oliver Schlaudt and an anonymous referee for reading the paper carefully and providing thoughtful comments, many of which have resulted in changes to the revised version of the manuscript.
} 


\section{Introduction}

A symposium on the assessment of public policies was held at the French National Assembly in June 2018 as a prefiguration of the national assessment office that will help elected representatives make their decisions. ${ }^{2}$ During the preliminary word, Esther Duflo has been presented by a MP as "the world reference regarding evaluation". ${ }^{3}$ In her introductory lecture, Duflo said her randomized evaluations (or randomized controlled trials, RCT) conducted at JPal are "inspired by behavioural economics". ${ }^{4}$ As a support to this statement, she contended that poor people (who are prime targets of these assessments) display behavioural biases that she considers as a-temporal and universal amongst such kind of population. In her Ely lecture given at the Annual Meeting of the American Economic Association in January 2017, she said a good economist should act and think like "a good plumber". This text actually teaches us little about the art of good plumbing, but this rhetorical process, which is less a metaphor than a way of establishing a benign complicity with the reader, or the listener, while overplaying a kind of empiricist modesty, serves among other things to anchor the analysis into behaviourism: "To summarize, economists have the disciplinary training to make good plumbers: economics trains us in behavioral science, incentives issues, and firm behavior” (Duflo, 2017:20). The aim here is therefore to remedy the supposed behavioural biases displayed by the poor by elaborating the "good" incentives ("a smart 'nudging' policy", ibid., p. 6) not on the basis of major theoretical or abstract principles but in a putative pragmatic way based on an empirical and concrete knowledge provided by behavioural economics.

\footnotetext{
${ }^{2}$ An op-ed in Liberation signed by about fifty researchers (Batifoulier et al., 2018) highlights the lack of diversity of the methods presented at this conference. A few weeks earlier, another newspaper column in Le Monde by nine researchers including three "Nobel" in economics (Bédécarrats et al., 2018) had highlighted the same methodological flaws. Another one has also been published in The Guardian in July (Alkire et al., 2018).

${ }^{3}$ https://youtu.be/4wiO7Iv37Ys?t=130

${ }^{4}$ https://youtu.be/4wiO7Iv37Ys?t=2754
} 
In an article published in the Journal of African Economics, Harrison had criticized the current randomized experiments as lacking the rigour of laboratory behavioural economic tests (Harrison, 2011). But he did not question the notion of behavioural bias shared with JPal randomisers among others. Thus, Harrison does not dispute the fact that randomisers, albeit not exemplary, can be part of behavioural economics.

RCT economists are not all behavioural economists and not all behaviourists practice randomized evaluation, especially Richard Thaler. This article focuses on the intersection between both groups. While they pretend to be largely pragmatic and only interested in what really works to solve practical problems it is crucial to point out their normative content and show that their approach is in fact based on clear-cut neoliberal ideological and political grounds (Servet, 2018). Most of the critical arguments highlighted in this article are not new. They have already been emphasised many times about mainstream economics and methodological individualism. The contribution of this article is to show the concrete form of some of these flaws in the work of behavioural randomisers.

The first section emphasizes that randomized behavioural experiments give a primacy to the individual. Despite intended pragmatism, these studies do not escape the long-time acknowledged limits of methodological individualism. The second section shows that these studies crucially centre, both positively and normatively, on economic and financial interdependencies by the Market to the detriment of public collective management or civil society controlling commons. In the third section, this paper proposes a discussion on the role of these behavioural randomized studies in the reproduction of the state in the neoliberal era. To do this, the discussion goes beyond the common opposition between the state and the market. The expertise provided by behavioural randomisers helps to subject people to incentives (positive or negative) that lead them to best fulfil the creed of a "good economy" inspired by neoliberalism. In doing so, the state becomes an agent of the Market. 


\section{Some concrete shortcomings of methodological individualism}

The design of the experiments and the processing of the data are carried out from an individualistic conception of social interactions which ignores contexts and composition effects and reflects the prejudices of those who are realizing these randomized evaluations. The data recorded by the technical assistants of the randomisers during the experiments are collected from individuals or households. These form the basis of each survey. The context is only mentioned in an exceptional way so the information communicated is then very rudimentary. This explains why randomisers do not seek to do interdisciplinary cooperation. Their science is essentially that of enumeration (Supiot, 2015). But it is limited to the collection of data from the statistically selected populations and their treatment. The aggregated data that would be captured in the community (meso level) and in the society (macro level) where these populations live are ignored (Maxwell, 2013). For example, the randomized evaluations presented in the American Economic Journal: Applied Economics in January 2015, measure the impact of microcredit on those who benefit from a loan as regard to control groups, a supposed similar population that does not benefit the treatment. Changes in income, investment or particular types of goods and services are examined. But the effect of possible competition distortions between micro-entrepreneurs induced by the benefit of that particular loan is not taken into account. As a result of such a positive discrimination, the beneficiary of the credit can for instance acquire a larger stock of raw materials at a lower cost or accept that her/his customers pay later on. If the beneficiary experiences an increase in turnover, and consecutively in income, consumption, savings and investments, it is reasonable to ask whether this is not to the detriment of micro-entrepreneurs neighbouring the same activity but not receiving a loan, as there is nothing in the experiment to prejudge an increase in aggregate demand. If the game is zero-sum at the sector level or 
community level, no positive economic impact can appear at the meso and global levels. Some authors (Banerjee et al., 2015: 24) mention that there can be general equilibrium issues but they do not incorporate them into the treatment and analysis.

Let us illustrate this primacy granted to the individual in behavioural RCTs by that led by Somville and Vandewalle in India on the incentive to savings (Somville and Vandewalle, 2018). It examines the effects on savings behaviour of a series of payments randomly paid in cash for some and as a deposit for others on a three months period. ${ }^{5}$ The focus is essentially on whether the money is retained or not by the respondent. If the money is not kept by the individual, the authors assume that the expenditure took place under the pressure of some short term need. ${ }^{6}$ In their perspective, a person is presumed as always subject to "bad behaviour" such as invariably rejecting choices that would be beneficial to her/him or to choose the satisfaction of immediate pleasures rather than more "useful" expenses later. However, it is possible to imagine that these sums of money that individuals no longer possess were not necessarily spent idly but lent to their entourage for example. For the authors, such a practice amounts to an expense or transfer deemed negative. They pay no attention to what this pocketed money during the trial can represent or mean for the respondents. The investigators ignore the fact that the "individuals" they study are inserted in a local community where they live on a daily basis of credit and debt relationships that entangle the economic and the social spheres. In this context, the loans made to the entourage are not to be necessarily interpreted by the researcher as a negative element induced by "social pressure". Lending to a close relation who is in dire need immediately opens the possibility that she/he or another close relation, responding to the same social and economic logic, will lend in her/his turn. Since the constitution of the discipline in the eighteenth century, the tribe of economists was formed against all these forms of solidarity and

\footnotetext{
${ }^{5}$ For a detailed critical review, see Servet (2018: 73, ff.).

6 Barnerjee and Duflo (2011) use the same prejudice as an assumption on individual behaviour.
} 
community logic. The so-called pragmatic modernity of behaviourists in general and of randomisers in particular shows here the weight of economic ideology.

In addition, the gap between the needs revealed by the populations and those supposed and ascribed by the designers of the evaluation can be very significant. Indeed, the central position of the individual in the trials does not automatically imply a perfect match between the goods or services disseminated for the tests and the needs of the populations tested (Jatteau, 2016). Frequently, alternative distribution modalities of a good or a service are tested as for instance the supply of electricity by solar panels, generators or an electric network (Anant et alii, 2014). Randomisers test a service, for example drinking water supply, wondering whether it is better to charge through meters at home or through paid public terminals where users would get supplies. But they do not wonder if people would prefer a public rather than private water supply for example. The designers of the experiment choose what is on the menu and these choices are not trivial, but reflect their own preferences without giving the tested population the opportunity to issue another option. The satisfaction of a need is not compared to the satisfaction of other potentially alternative needs. Of course, another survey could offer other options, but such a bias in the questionnaire has a strong influence on the final result; it is a basic methodological question in all the social sciences. To what extent such experiments are really different from a mere market study on the price level of solvent demand? In addition, the utility of the good or service under test is not called into question by the authors of the tests because the goods tested are presumed to express a progress or a development whose content is not itself put into question. However, witnesses and randomized test subjects say that, after being tested, mosquito nets, condoms, chlorine tablets purifying water, and so on are frequently left abandoned (Jatteau, 2013:20). After distribution, insecticide-treated mosquito nets were not placed over the beds of humans but were used to protect goats from mosquito bites, for example. This illustrates the mechanisms 
of diversion, appropriation of "development aids" and the many sham behaviours they elicit. These drawbacks are certainly no less important than what has been denounced in the past about official development assistance.

To understand the origin of these failures, one must analyse the process from the initiative of the test to the final decision to test. In the best case, the instigation comes from a development organization in contact with the populations, which wonders for example why this supply of services or goods meets only mitigated success. In these cases, RCTs turn merely to be a way to improve the organisation's marketing campaigns. In the worst case (given actual local needs), the initiative comes from researchers who have received support from a donor and contact local organizations to apply the test in exchange for certain benefits such as compensation for their field agents, or vehicles left after the experiment, etc. Most of the time, this information on funding and budget allocation is not indicated in articles reporting on experiments.

One of the authors of this article (Servet) has reviewed, for a public funder, a research project in western Cameroon to randomly test the transformation of local rotating savings and loan associations into risk and solidarity hedging instruments. In this area, however, tontines with the largest financial volume are auctioned, which is incompatible with a logic of mutual behaviour. This illustrates the strong misunderstanding that these researchers had of the milieu in which they planned to work. The referee learned later on that the other evaluator had also expressed a very negative opinion on this project because of the great ignorance of the field.

Another example reported by Arthur Jatteau (Chartrain, 2017) concerns an attempt to install sanitary equipment in rural villages in Kenya. Once the equipment was put in place, researchers who supervised the study were asked to return to the villages one year later to observe whether the villagers still used the equipment. However, the researchers refused on 
the pretext that utilization rates could be too low, or even zero, and that they needed tangible results for their future publications. The decision was then made to return only a few weeks after the installation of the equipment to take advantage of the novelty effect they would elicit. This temporal element reveals a deep discrepancy between the method and the object. While development takes decades, surveys are carried out in a few months without questioning the stability and the duration of the behaviours observed. The need to publish at all costs and as quickly as possible pushes these "researchers" to neglect the deep facts that are part of the slowness and duration of social life.

Randomized trials, as well as computer-based tests, being focused on the individual do not capture the effects of effects, i.e. systemic relations. There exist loop side effects with positive or negative feedbacks. Sometimes these effects are even overlooked at the individual level. For example, in the mosquito net trial, the evaluators (Cohen and Dupas, 2010) did not care about the type of insecticide coating the mosquito nets. Mosquito nets are usually impregnated with pyrethroids but it appeared that this product could cause adverse effects on the cognitive development of the child for pregnant women. ${ }^{7}$ Similarly, in the tests on the effects of a vermifuge on school absenteeism, the randomisers did not wonder whether or not a greater presence at school would really increase school performance, mistakenly prejudging a positive impact. ${ }^{8}$

\section{A pro-market twist?}

Behavioural randomisers presume that market exchanges are the most effective form of regulation for societies reduced to their economic base. In the RCT they conduct in India, Somville and Vandevalle consider that a reduction in the use of cash for payments on accounts would reduce durably the consumptions considered "not essential". As a result, this

\footnotetext{
${ }^{7}$ About the effects of pyrethroids, see Viel et ali. (2015).

${ }^{8}$ Miguel and Kremer (2004).
} 
would cause an increase in household savings. This financial "nudge" is supposed to induce poverty reduction, a small impulse with a great result. Unfortunately, this enchanting sequence is probably illusory. All suggest that the savings of these poor households are more or less rapidly absorbed by the shocks they suffer in the absence of protection against risks, especially in the event of illness or death of a member who used to provide a large share of the family income. ${ }^{9}$ This need for protection implies the establishment of public support for the development of both health insurance institutions and health services. ${ }^{10}$ It is difficult to imagine that care structures and prevention systems can be effectively established by the mere use of "market laws" and the free expression of individual preferences. In fact, this has never been observed in history: all the existing systems of social protection and prevention have been set up by public authorities and by community or mutual organisations. Before the 20th century and the nationalization of insurance schemes, these were associations which took charge of the voluntary contributions of their members to certain risks (Laville, 2010 for the 19th). Neither the public nor community associations made it a profit logic.

Let's take another example, among hundreds of other possible, to account for the mercantile bias of randomisers: a study on the use of a toilet emptying system in Dakar. ${ }^{11}$ As indicated in the title, this study is about testing private and commercial solutions to imagine how to encourage them. What is at stake is a new pumping system that is more efficient than manual emptying. The question is how to get more households willing to pay more for something less polluting and faster? Less than a third of households use mechanical pumping, which is costly compared to shovel evacuation, the equivalent of five to three days' wages. The authors explain their study by highlighting the health consequences of the poor disposal of

\footnotetext{
${ }^{9}$ In the same vein, Bryan and Rafferty (2018) show how households are becoming the shock absorbers of last resort including in advanced economies.

${ }^{10}$ For an analysis of the case of the United States cf. Zelizer (1979).

${ }^{11}$ This study in progress is led by Jean-François Houde, Molly Lipscomb and Laura Schechter, cf. Market Structuring of Sludge Management for the Benefit of Vulnerable Households in Dakar, https://www.poverty-action.org/study/market-structuring-sludge-management-benefit-vulnerablehouseholds-dakar.
} 
wastewater and excrement, resulting in particular in increased infant mortality. Here stops their concern for the collective. All major European cities have built in their development phase and have since maintained a public sewage system and treatment plants to evacuate and wash the different categories of wastewater. Has not such a system proved its efficiency in meeting the needs of the greatest number? The question of a more modern evacuation of excrements will arise anyway. In Dakar, 59.3percent of houses have a septic tank, 6.4percent have a sealed pit, 3.5percent use latrines and 0.1percent have no sewage system, 30.6percent of homes are already connected to a sewer (SRSD Dakar, 2013, chap. 5:51). ${ }^{12}$ It is true that the local press regularly emphasizes the lack of maintenance of this system but the development of such a public solution is not even mentioned by randomisers. They do not even consider dry toilet although this is the most environmentally friendly solution. ${ }^{13}$ The only solution under test is a private and mercantile modality. The test involves 4000 households who will receive a reduction of 10 or 50percent on the cost of mechanical pumping. The effect on neighbours who do not benefit from the subsidised service is also tested. The emphasis on the market and the individual dimension of the test is reinforced by the type of financial arrangements envisaged, in particular the timing of the payment and its linking with savings accounts to cover this type of expense. Other tests, like those conducted in Morocco (Devoto et al., 2012) to encourage the installation of drinking water meters at home have the same commercial bias, which tends to legitimise the involvement of water suppliers like Veolia to expand their clientele. The same question arises about the tests relating to the domestic production of electricity by means of solar panels where private

\footnotetext{
${ }^{12}$ The summary of the study indicates that it takes place in Dakar. It should be noted that the sewer is much less used outside the department of Dakar. In its suburbs, the most common mode of sewage disposal is the septic tank; it concerns 99percent of concessions in Guédiawaye, 62.18percent in Pikine and 91percent in Rufisque.

${ }^{13}$ One might think that this solution is only valid for rural areas. But the equipment in dry toilets of the premises of the Charles Léopold Mayer Foundation for the Progress of Humankind in the XIth arrondissement of Paris shows the possible use in city.
} 
companies seem always preferred to a supply of electricity by networks articulating private and collective logic and supposing public investments (Anant et al., 2014).

The pro-Market bias for its presumed competitive mechanisms is pervasive in a great deal of tests conducted, for example, in India and Indonesia to eliminate or restrict corruption in the distribution of public aid (Olken, 2007, Banerjee et al., 2016). In these approaches, the market is not understood as a social construct but as a "mechanism" of supplies and demands whose price process is never clearly analysed. ${ }^{14}$ In many cases, the authors of these tests assume that government intervention at both the national and local levels inevitably leads to rent capture, which has a negative effect on economic activity. The appropriation of the state by private interests is presumed somehow inherent to public intervention and new distribution procedures are supposed to eliminate or restrict it. These studies imagine state operating rules considered as normal without calling into question the nature of the State in these societies. Nor do they question the possible clannish functioning of the State, the economy of gift and counter-gift in social relations, the level of remuneration of civil servants in relation to other social categories, etc. It is also important to consider the direction and distribution of financial flows induced by what is usually called "corruption". If the extracted resources are then invested abroad, their effect and significance is probably not the same as if they are used to fuel expenditures in the local economy and provide jobs. In this case, buying citizens' votes can be a redistributive system of wealth. Inspired by a sort of fair price ideal (including regarding public expenditures), randomisers are unable to grasp such systemic effects. However, these politico-cultural and economic elements should be taken seriously in order to hope to eliminate corruption in a global way. ${ }^{15}$

\footnotetext{
${ }^{14}$ For an introduction to this old but overlooked question by mainstream economics, see for instance Berta et al. (2012), Bénicourt and Guerrien (2008) and Kirman (2011).

${ }^{15}$ This point is less addressed to RCTs than to neoliberalism in general, and it is not a question here of saying which research method could eliminate all corruption in a global manner.
} 
Some tests, for example on the effectiveness of accompanying unemployed people to find a job, note that public institutions are as effective as private institutions while their costs are lower. ${ }^{16}$ One could then conclude that randomisers are not systematically victims of a promarket bias but a thorough reading of the papers reveals anyway a strong prejudice that the market is the most effective regulation modality of societies. ${ }^{17}$

\section{Public intervention at the service of the Market}

Putting public intervention into the service of the Market, understood as the competition of private interests and property (Hillenkamp and Servet, 2015), is a central element of the neoliberal configuration. Commentators often oppose behavioural economists to neoliberals in that the former rely heavily on public structures (national as well as multilateral). Just as State / Market opposition is very much a rhetorical and political game rather than a historical and organizational reality (Andreau et ali., 2006, Théret, 1992, Elias, 1939), the mistake here is to think that neoliberals would systematically oppose the State. They oppose a State socialising part of the activity by producing directly goods and services, but not a State that contributes to the institution of what they consider to be the proper functioning of competition and the defence of private property rights. They want a State as sustainer of the Market order (Mitchell and Fazi, 2017, chap.5). Rather than only economic activities, the

\footnotetext{
${ }^{16}$ Cf. Crépon et ali, (2011) and Ferracci and Martin, (2013). Crepon et ali. (2011:3) develop a promarket justification: "this finding remains hard to interpret, because the counselling market has only recently been opened to the private sector: it is possible that private providers price over their marginal cost in a market in infantry where competition is limited". Yet, in the initial French version of the 2009 Report, this explanation is absent: "the weaker performance of PPOs could be explained by the need to train newly recruited staff in recent structures: however, in our sample of 12 cohorts, we do not observe a strengthening of the overall PPOs impact through time" (our translation).

${ }^{17}$ In their opinion, all the dimensions composing the social are reduced to the economic dimension which economy is itself analysed through a sort of folkish methodological individualism. The preceding remarks are also valid for the extension of the tests to the political field and to the choices exercised by voters who are then considered as consumers of services and public goods. These tests were conducted in India (Banerjee et al., 2011), Indonesia (Olken 2007, 2009), Brazil (Ferraz and Finan, 2008), and Mexico (O. Chong et al., 2011). The fact that randomizers do not systematically reject public intervention creates an illusion for those who ignore the relationship between the State and the market in neoliberal thinking.
} 
neoliberal doctrine considers that all human activities have to be conceived in terms of market and competition of private interests. Hence, the State has to be both the builder and the protector of a genuine market-based society.

In the classic vision that goes from Smith to Samuelson through Walras and many others, the state is responding to the market and private sector failures (resulting from externalities, increasing returns etc.) and thus acting directly in place of a private monopoly. In the postwar period, economists like Musgrave and others have developed public economics around the idea that when neoclassical price theory doesn't apply because real conditions are too far from required hypotheses, then the government can operate directly instead of private initiatives and (under certain conditions) achieve a second best optimum. Since its beginning, the neoliberal doctrine is based on a rejection of such kind of mixed economy on the grounds that the direct intervention of the state is the ferment of socialism (Audier, 2008, Jones, 2012). This doctrine has two sides. On the one hand, the notion of state failures (Kahn, 1995) leads to the rejection of any form of nationalization of activity (i.e. production and trade) or social provisioning. On the other hand, the notion of the State-as-a-regulator (or sustainer of the Market order) ensures the institution of the market and capitalist relations, which are not spontaneous but need to be protected against the reactions of the society itself as noticed long time ago by Polanyi (1944). ${ }^{18}$

Most of contemporary behavioural economists and randomisers are contributing to the toolkit of the neoliberal State-as-a-regulator. It is from this perspective that the positive or negative incentives ("nudges") offered by behavioural economics make sense. They aim to normalize the behaviour of consumers, users, employees or small/independent producers. From a Foucaldian point of view, these "nudges" are part of a set of power devices by which

\footnotetext{
${ }^{18}$ A pionneer contribution in economics is Coase (1960). Against this political vision, Karl Polanyi has developed the opposite idea that society must develop specific protections to survive the generalization of market exchanges (Hillenkamp, Laville 2013; Laville 2010, Laville et alii 2017, Maucourant and Plociniczak, 2013; Mendell 2007).
} 
individual behaviours are modelled and forced, without their knowledge, to conform to the class interests that dominate them. ${ }^{19}$

The founders of neoliberalism have affirmed the importance of a politically strong state to enable the most meticulous regulation of production and trade. Yesterday, this intervention was conceivable for these thinkers by a constraint that could go up to a dictatorship. Today, the constraint can be soft thanks to the proposed and tested incentives. Experts who claim to be behavioural economists are there to think about these incentives and measure their effects. They claim that their contribution is only depoliticized technical support. They would be the ones that enable policy makers to make informed choices. And they turn out to be neoliberal policy experts. The difference between behavioural randomisers, on the one hand, and patented neoliberals, on the other, is that the former claim they are pragmatic, while the latter think of the need for structuring theoretical thinking (see table 1 below). Ironically, the former can be put under the criticism of Friedrich von Hayek himself: "Applying to each task the 'social techniques' most appropriate to its solution, unfettered by any dogmatic belief, seems to some the only manner of proceeding worthy of a rational and scientific age... Those self-styled modern 'realists' have only contempt for the old-fashioned reminder that if one starts unsystematically to interfere with the spontaneous order there is no practicable halting point and that it is therefore necessary to choose between alternative systems. They are pleased to think that by proceeding experimentally and therefore 'scientifically' they will succeed in fitting together in piecemeal fashion a desirable order by choosing for each particular desired result what science shows them to be the most appropriate means of achieving it" (Hayek 1973: 57-8).

${ }^{19}$ In the late 1970s, the word "nudge" was not yet used as it is today, but Foucault (2008) expresses this idea when he writes "Homo œconomicus is the interface of government and the individual" (p. 252-3). 
[insert table 1]

\section{Conclusion}

Behavioural randomisers are now enjoying a success that is not dissociated from the general neoliberal context. After a first development in the 1960s, the method of behavioural tests carried out in the form of experiments of the "great society" in the United States has been pushed into the background (Jatteau, 2017) before being reborn in the 2000s and reaching the heights today with the Sveriges Riksbank Prize in Economic Sciences in Memory of Alfred Nobel prize for Richard Thaler in 2015 and for Abhijit Banerjee, Esther Duflo and Michael Kremer in 2019. Before the reign of neoliberalism in the 1980s, these experiments failed to gain a foothold in prestigious academic institutions, as is the case today. A deep reason for their faint seduction in the past is undoubtedly that, at that ante-neoliberal time, it was doubtful for many to forget society and to pretend to solve "social" problems by treating only individual behaviour. The conviction of the collective determinants was then strong. There is still a need to go beyond the narrow nature of an individual-centred approach to include systemic effects, trends and counter-trends. It is necessary to uncover an alleged pragmatism and to warn about the dangers of this increasingly dominant method in social sciences and correlatively in the evaluation of social and development policies. It is not about claiming that there is no worse methodology than RCTs but their practice by behavioural economists is questionable and leads to biased results. Better random tests could be carried out taking into account the context, historicity, feedback, social and macroeconomic determinants, links and interactions with community and society; by not predetermining in advance the result on the researchers' preferred choices, by not presuming that the researcher knows better than the interviewee what is good for him / her; by taking the time to study the feedback effects (positive or negative) of the survey and its recommendations, by being more 
aware that the respondents "play" with the interviewers; by taking into account social habits over time, and making interdisciplinary cooperation; and by taking into account composition effects (what is true at the micro level is not necessarily so for society as a whole). Last but not least, this method cannot replace other methods in the social sciences, be they qualitative or quantitative. It is therefore not rational for the RCTs to capture a gigantic share of public resources intended to finance development projects.

References

Alkire, Sabina et al. (2018). Buzzwords and tortuous impact studies won't fix a broken aid system. The Guardian, July $16^{\text {th }}$, https://www.theguardian.com/globaldevelopment/2018/ju1/16/buzzwords-crazes-broken-aid-system-poverty

Anant Sudarshan, Greenstone Michael, Ryan Nick, Burgess Robin (2014) Welfare Benefits of Decentralized Solar Energy for the Rural Poor in India. Presentation at EPIC India Seminar Series presentation, Delhi, India, September 30 [https://cpb-usw2.wpmucdn.com/campuspress.yale.edu/dist/5/91/files/2014/10/bgrs_value_of_solar_20170 9-1q6ldx5.pdf].

Andreau J., G. Béaur and J.-Y. Grenier (ed.) (2006) La dette publique dans l'histoire. Paris: Comité pour l'histoire économique et financière de la France.

Audier Serge (2008). Le colloque Lippmann. Aux origines du néolibéralisme. Éd Le bord de l'eau. 
Batifoulier, Philippe et al. (2018). Politiques publiques: vers une évaluation bien trop aléatoire. Liberation, June $20^{\text {th }}$, http://www.liberation.fr/debats/2018/06/20/politiquespubliques-vers-une-evaluation-bien-trop-aleatoire_1660716

Barnerjee, Abhijit V. and Esther Duflo (2011). Poor Economics, A Radical Rethinking of the Way to Fight Global Poverty. New York, Public Affairs.

Banerjee, Abhijit V. et alii (2011) Do informed voters make better choices? Experimental evidence from urban India. Working Paper.

Banerjee, Abhijit, Esther Duflo, Rachel Glennerster, and Cynthia Kinnan (2015). The Miracle of Microfinance? Evidence from a Randomized Evaluation. American Economic Journal: Applied Economics, 7(1): 22-53; http://dx.doi.org/10.1257/app.20130533

Banerjee, A., E. Duflo, C. Imbert, S. Mathew, and R. Pande (2016). E-governance, Accountability, and Leakage in Public Programs: Experimental Evidence from a Financial Management Reform in India. NBER Working Paper No. 22803

Bédécarrats, Florent et al. (2018). L’aide au développement passe par des réformes. Le Monde, Mai $23^{\text {rd }}$, https://www.lemonde.fr/idees/article/2018/05/22/1-aide-au-developpementne-peut-se-contenter-des-micro-interventions-visant-des-individus-et-agissant-a-courtterme 5302809_3232.html 
Bénicourt, Emmanuel et Bernard Guerrien (2008). Is Anything Worth Keeping in Microeconomics?. Review of Radical Political Economics, 40(3): 317-23.

Berta, Nathalie, Ludovic A. Julien and Fabrice Tricou (2012). On perfect competition: definitions, usages and foundations. Cahiers d'économie Politique / Papers in Political Economy, 63: 7-24.

Bryan, Dick and Mike Rafferty (2018). Risking together. Sydney University Press.

Chartrain, Laura (2017). Gros plan sur... La thèse de Arthur Jatteau, sur "Faire preuve par le chiffre? Le cas des expérimentations aléatoires en économie". Sociologie économique, Carnet du RT12 de l'Association Française de Sociologie, https://socioeco.hypotheses.org/3393

Chong Alberto, O Ana L. De La, Karlan Dean, Wantchelon, (2011). Looking beyond the incumbent: the effects of exposing corruption on electoral outcomes. National Bureau of Economic Research, Working Paper n ${ }^{\circ} 17979$.

Coase, Ronal (1960). The problem of social cost. The Journal of Law and Economics, 3: 1-44

Cohen Jessica and Dupas Pascaline. (2010) Free distribution or cost-sharing? Evidence form a randomized malaria prevention experiment. The Quarterly Journal of Economics, 125 (1): $1-45$.

Crépon B., Gurgand M., Kamionka T., Lequien L. (2009). Evaluation d'impact de l'accompagnement des demandeurs d'emploi par les opérateurs privés de placement et le 
programme Cap vers l'entreprise

[https://www.povertyactionlab.org/sites/default/files/publications/87\%20Rapport_final_OPP \%20CVE_2.pdf]

Crépon B., Gurgand M., Kamionka T., Lequien L. (2011). Is counseling welfare recipients cost-effective? Lessons from a random experiment. Document de travail Crest

Devoto, F., E. Duflo, P. Dupas, W. Pariente, and V. Pons (2012). Happiness on Tap: Piped Water Adoption in Urban Morocco. American Economic Journal: Economic Policy 4(4): 6899.

Duflo, Esther (201). The Economist as Plumber. Ely Lecture, American Economist Association Meeting, January $23^{\text {rd }}$, https://economics.mit.edu/files/12569.

Elias, Norbert, (2000). The Civilizing Process. Oxford: Blackwell (original edition in German, 1939).

Foucault, Michel (2008. The birth of biopolitics: lectures at the Collège de France, 1978-79. Translated by G. Burchell, New York, Palgrave Macmillan.

Miguel, Edward and Michael Kremer (2004). Worms: identifying impacts on education and health in the presence of treatment externalities. Econometrica, 72 (1): 159-217 
Ferracci Marc, Martin Florine, (2013) Évaluation par expérimentation aléatoire de dispositifs de reclassement innovants pour les demandeurs d'emploi. Travail et emploi $\mathrm{n}^{\circ} 135$, juil.-sept. 2013, p. 15-26, [https://journals.openedition.org/travailemploi/6051]

Ferraz, Claudio and Frederico Finan (2008) Exposing corrupt politicians: the effects of Brazils' publicity released audits on electoral outcomes. The Quarterly Journal of Economics, 123 (2): 703-745

Harrison, Glenn W. (2011). Randomisation and its discontents. Journal of African Economies, 20 (4), August 2011: 626-652.

Hayek, Friedrich A. (1973). Law, Legislation and Liberty, Vol. 1 Rules and Order. Routledge and Kegan Paul Ltd (1982).

Hillenkamp Isabelle, Laville Jean-Louis (ed.), (2013). Socioéconomie et démocratie l'actualité de Karl Polanyi. Toulouse, Erès.

Hillenkamp I., Servet J.-M. (ed.), (2015). Le marché autrement. Marchés réels et Marché fantasmé. Paris, Garnier.

Jatteau, Arthur (2013). Expérimenter le développement ? Des économistes et leurs terrains. Genèses, 93: 8-28. DOI : 10.3917/gen.093.0008.

Jatteau, Arthur (2016). Faire preuve par le chiffre ? Le cas des expérimentations aléatoires en économie. Thèse Université de Paris-Saclay. 
Jones, Daniel Steman (2012). Masters of the Universe: Hayek, Friedman, and the birth of neoliberal politics. Princeton University Press.

Kahn, Mushtaq (1995). State Failure in Weak States: a Critique of New Institutionalist Explanations. in J. Harriss, J. Hunter and C. Lewis (ed.) The New Institutional Economics and Third World Development. Routledge, London 1995: 71-86.

Kirman, Alan (2011). Market Mechanisms in Real Markets: Why did markets disappear from Economic Analysis? School and Workshop on Market Mechanism Design, ICTP Trieste, March.

Laville Jean-Louis (2010) Politique de l'association. Paris, Le Seuil.

Laville Jean-Louis, Elisabetta Bucolo, Pleyers Geoffrey, Coraggio Jose Luis (eds.) (2017). Mouvements sociaux et économie solidaire. Paris, Desclée de Brouwer.

Maucourant, Jérôme and Sébastien Plociniczak (2013). The Institution, the Economy and the Market: Karl Polanyi's Institutional Thought for Economists. Review of Political Economy, 25 (3): 512-531, DOI: 10.1080/09538259.2013.807675

Maxwell, Simon (2013). Poor Economics: a review. Journal of International Development, 25 (7): 1026-1032, http://www.simonmaxwell.eu/book-reviews/poor-economics-a$\underline{\text { review.html }}$ 
Mendell Marguerite, (2007). Karl Polanyi et le processus institué de démocratisation politique. Revue du Mauss, n²9, p. 444-464.

Mitchell, William and Thomas Fazi, (2017). Reclaiming the State. Pluto Press.

Olken Benjamin A., (2007). Monitoring corruption: evidence form a field experiment in Indonesia. Journal of Political Economy, vol. 115 (2): 200-249.

Olken Benjamin A., (2009) Corruption perceptions vs. Corruption reality. Journal of Public Economics, 93 (7-8): 950-964

Polanyi, Karl (1944). The Great Transformation. Beacon Press (2001).

Servet, Jean-Michel (2018). L'économie comportementale en question. Paris, éditions Charles Léopold Mayer.

Service Régional de la Statistique et de la Démographie (SRSD) de Dakar (2013). Situation économique et sociale régionale 2013. ANSD, http://www.ansd.sn/ressources/ses/SES-

Dakar-2013.pdf

Somville, Vincent and Lore Vandewalle (2018) Saving by Default: Evidence from a Field Experiment in Rural India. American Economic Journal: Applied Economics, 10(3): 39-66.

Supiot, Alain (2015). La gouvernance par les nombres. Paris, Fayard. 
Théret, Bruno, (1992). Régimes économiques de l'ordre politique : esquisse d'une théorie régulationniste des limites de l'Etat. Paris: Presses Universitaires de France.

Viel, Jean-François, Charline Warembourg, Gaïd Le Maner-Idrissi, Agnès Lacroix, Gwendolina Limon, Florence Rouget, Christine Monfort, Gaël Durand, Sylvaine Cordier, Cécile Chevrier (2015). Pyrethroid insecticide exposure and cognitive developmental disabilities in children: The PELAGIE mother-child cohort. Environment International, 82: 69-75, https://doi.org/10.1016/j.envint.2015.05.009.

Zelizer, Viviana A. (1979). Morals and Markets. The Development of Life Insurance in the United States. Columbia University Press.

Jean-Michel Servet is honorary professor of the Graduate Institute of International and Development Studies in Geneva and Triangle Center associated researcher (Ecole Normale Supérieure de Lyon, CNRS, Université Lyon 2). He has done field works in Western and Northern Africa, South India, Latin America and Western Europe for the last forty years. His researches deal with social finance and solidarity alternatives, financial inclusion, local and complementary money, financial globalization, commons, and interdisciplinary methods in social sciences. He is also an historian of economic thought.

Bruno Tinel

Corresponding author, btinel@univ-paris1.fr +33674838297

Maison des Sciences Economiques 
Université Paris 1 Panthéon-Sorbonne

106-112 Boulevard de l'Hôpital

75642 Paris Cedex 13, France

Bruno Tinel is Associate Professor at the Sorbonne School of Economics of the University of Paris 1 Panthéon-Sorbonne and a member of the Centre d'Economie de la Sorbonne (UMR 8174). His research is on the related transformations of both public finance and finance through history. 